Вісник ЛНУ імені Тараса Шевченка № 3 (334), 2020

УДК 37.062 .2

DOI: 10.12958/2227-2844-2019-3(334)-205-212

\title{
Сы Цзюньцинь,
}

доктор филологических наук, профессор факультета русского языка и литературы Института иностранных языков и литератур

Ланьчжоуского университета, г. Ланьчжоу, Китай

sytsziuntsin@gmail.com

https://orcid.org/0000-0002-9637-0748

\section{ОБУЧЕНИЕ РУССКОМУ ЯЗЫКУ В КИТАЙСКИХ ВУЗАХ В КОНТЕКСТЕ ИНИЦИАТИВЫ „ОДИН ПОЯС И ОДИН ПУТЬ”}

В контексте инициативы „Один пояс и один путь” отношения Китая Украины, Беларуси и России также получили новый виток в своем развитии. При этом сотрудничество в экономической, политической и культурной областях увеличили спрос на специалистов, владеющих русским языком. Курсы русского языка постепенно включаются в такие различные области, как финансы, торговля, юриспруденция, медицина и другие. Об этом писали Нин Ци, Лу Чуньюэ, Цао Тайшэн, Лэй Ваньпэн, Чжоу Минцюань и другие. Однако они не затрагивали путей решения проблем, связанных с реализацией государственной инициативы „Один пояс и один путь”. Для того, чтобы способствовать повышению уровня обучения русскому языку в китайских вузах и подготовить лучших специалистов, мы должны понимать существующее состояние обучения русскому языку и определить проблемы, которые мешают эффективной реализации проектов, направленных на методическое и научное совершенствование преподавания русского языка. Все это обусловливает цели и задачи нашей статьи, которая заключается в стремлении изучить особенности реализации проекта „Один пояс и один путь” в рамках языковой подготовки специалистов.

После заявления лидером Китая инициативы „Один пояс и один путь” мы констатируем растущий спрос на специалистов, владеющих в совершенстве русским языком. „Согласно неполным статистическим данным, за последние десять лет в стране было добавлено более 60 специиальностей русского языка, а 30 исследовательских учреждений по исследованиям национальных и региональных вопросов были утверждены Министерством образования. Форма, масштаб, специифика культурных обменов достигли беспрецеедентных уровней и создали модель цивилизованного диалога" (Нин Ци, с. 2019, с. 76).

В настоящее время в Китае имеется больше 160 университетов или институтов, в которых открыта специальность „Русский язык”. Сегодня существуют не только иностранные языковые университеты, у которых есть специальность „русский язык”, но и большое количество многопрофильных университетов также создали подобные 


\section{Вісник ЛНУ імені Тараса Шевченка № 3 (334), 2020}

специальности. Нужно отметить, что и политехнические университеты включили специальности, связанные с изучением русского языка в свои профессиональные направления.

Что касается учебного плана, то в его состав включены такие базовые курсы, как грамматика, аудирование, разговорная речь, введение в литературу, история культуры, теория перевода и курс по международным отношениям. Некоторые университеты также обращают внимание на обучение таким практическим учебным предметам, как деловой русский язык, СМИ, практика перевода и другие дисциплины, которые в основном предлагаются в форме факультативных курсов. Это в значительной степени отвечает потребностям студентов, стремящихся совершенствовать свои практические навыки владения русским языком, целью которого является оптимизация структуры знаний студентов и расширение их мировоззрения.

Нужно отметить, что во многих университетах проводят разнообразные воспитательные и учебные мероприятия. Скажем, за пределами аудитории в университетах создаются специальные кабинеты русского языка, в которых в свободное от обучения время студенты организовывают беседы, обсуждения, диспуты, которые касаются русского языка и русской культуры. Кроме того, в некоторых университетах проходит ежегодный фестиваль, который знакомит с различными аспектами с украинской, русской, белорусской, казахской культуры и искусства (с литературой, живописью, театром, кино, кулинарией). Все это в значительной степени способствует актуализации обучения русскому языку.

Скажем несколько слов о конкурсе русского языка. Это мероприятие, проводимые ежегодно по всей стране, является грандиозным событием для талантливых студентов, целью которого является содействие культурным обменам, развитию изучения русского языка, а также отбор, обучение и резервирование для страны высококлассных специалистов, владеющих русским языком.

В современных условиях глобализации многие университеты стремятся К интернационализации образования, которое будет способствовать интерактивному сотрудничеству и диверсифицированному развитию. Возможности студенческого обмена с Украиной, Беларусью, Россией, Казахстаном и другими странами доступны во многих учебных заведениях Китая. Студенты обычно после второго курса выезжают за границу на один год обучения и учатся в этих странах на третьем курсе. Ежегодно государственный фонд образования отбирает и полностью субсидирует наиболее успешных студентов, связанных со специальностью русского языка, для обмена и обучения в различных университетах Украины, Беларуси, России. Обучение и зарубежный обмен способствуют эффективной помощи студентам для преобразования теоретических знаний в практические навыки владения устной речью. Помимо этих лингвистических задач обмен способствует и расширению кругозора студентов. 
Вісник ЛНУ імені Тараса Шевченка № 3 (334), 2020

Уровень занятости выпускников специальности „русский язык”, как правило, находится на высоком уровне. После окончания обучения выпускники могут поступить работать в учебные заведения, переводческие и внешнеторговые компании, государственные учреждения и так далее.

В последние годы обучение русскому языку в китайских университетах достигло значительных результатов, но в то же время оно сопровождается рядом новых проблем и вызовов.

Обучение русскому языку во многих вузах является изолированным и в основном не имеет контакта или смешения с другими дисциплинами. „Хотя некоторые университеть пытаются интегрировать предметь специиальности „русский язык” с другими дисииплинами, междисииплинарные курсы все еще отсутствуют в существующей учебной программе, и эти барьеры являются серьезными" (Цао Тайшэн, Лэй Ваньпэн, 2005, с. 15).

Практика и стажировки особенно важны в обучении студентов иностранным языкам, в том числе и русскому. Недостаточная база стажировок для студентов по специальности „русский язык” в некоторых университетах также является распространенной проблемой. Из-за небольшого количества учебных учреждений Китая, где можно проходить учебную практику, студенты не могут в достаточной степени реализовать полученные умения и навыки.

Одной из проблем обучения русскому языку в Китае является тот факт, что ряд университетов сосредотачивает внимание на академическом образовании студентов, игнорируя постижение учащимися культуры и искусства тех стран, в которых распространен русский язык. Так же существующие подходы к обучению демонстрируют ведущую роль преподавателя, и студент, к сожалению, играет здесь пассивную роль. Единый метод обучения ведет к единому методу оценки, и в настоящее время общепринятой практикой контроля в университетах Китая является проведение письменного теста в середине и конце семестра. Этот метод единого теста не способствует развитию и улучшению творческих способностей студентов. Поэтому мы стараемся создать комплексный механизм оценки и использовать комбинацию письменных и устных тестов в процессе обучения. Это делает занятия в течении семестра максимально эффективными и способствует формированию высоких результатов в общем балле оценки.

В соответствии с новыми требованиями, которые сформулированы в рамках реализации программы „Один пояс и один путь” и нового „Национального стандарта”, в Китае выдвинуты модернизированные стандарты профессионального обучения русскому языку. Эта реформа в основном затрагивает профессиональные функции, модели обучения будущих специалистов и совершенствование команды преподавателей. Разработка инновационной модели обучения русскому языку является приоритетной задачей для многих специальностей в вузах.

В контексте инициативы „Один пояс и один путь” Китай активно 


\section{Вісник ЛНУ імені Тараса Шевченка № 3 (334), 2020}

сотрудничает с Украиной, Беларусью, Россией в сферах энергетики, транспорта, финансов, экологии и охраны окружающей среды, а также в сфере высоких технологий. Но если не хватает специалистов, хорошо владеющих русским языком и обладающих соответствующими профессиональными знаниями, достаточно сложно добиться сотрудничества между странами. Чтобы преодолеть это слабое звено в межгосударственном взаимодействии, университеты должны использовать транснациональное сотрудничество, которое способствует интеграции и обмену качественных учебных ресурсов и профессиональных преподавателей.

Подготовка прикладных специалистов русского языка не происходит в одночасье. Развитие будущих профессионалов должно осуществляться в соответствии с потребностями социальноэкономической программы. $\mathrm{B}$ процессе развития мы должны сосредоточиться на правильном решении возникающих проблем, и только так мы сможем открыть более широкие возможности для обучения русскому языку в китайских вузах. Как отметил профессор Чжоу Минцюань: „С точки зрения развития специальностей русского языка в стране и за рубежом страноведение и краеведение стали неотъемлемой и важной частью преподавания русского языка в вузах" (Чжоу Минцюань,2015, с. 23).

Считаем так же, что сегодня существует острая необходимость создания исследовательской группы, сосредоточенной на внедрении и адаптации выдающихся академических достижений украинских, российских, белорусских университетов. Поэтому необходимо организовать совместную команду для различных академических исследований. Все это станет гарантией подготовки профессиональных лингвистов.

В Китае университеты оправляют преподавателей для стажировки в те страны, где есть носители русского языка: в Украину, Беларусь и Россию. Все это осуществляется при поддержке государственных программ и проектов Национального стипендиального совета. Данный метод „выхода” преподавателей - эффективный способ улучшить преподавательские и исследовательские возможности. Преподаватели, обучающиеся в Украине, России и Беларуси, не только повышают свой профессиональный уровень, но и изучают русский язык, обучаются методам преподавания русского языка как иностранного и осваивают новейшие разработки данной дисциплины. Только когда преподаватели стремятся обучаться в течении всей жизни, они могут достичь непрерывного развития в методической и исследовательской работе.

Мы полагаем, что, когда в университеты приглашают иностранных преподавателей, которые являются носителями русского языка, то это не только устраняет нехватку преподавателей, но и способствует развитию научных исследований по специальностям, связанным с русским языком и литературой. Иностранные специалисты могут не только преподавать курсы по таким языковым дисциплинам, как 
аудирование и говорение, письмо, русская литература, русские новости, избранные русские газеты, русское общество и культура, но они также могут участвовать в научных исследованиях (см. Лу Чуньюэ,2019).

Отметим, что настоящая статья - результат проекта общеобразовательного курса „Оценка русских классических литературных произведений” в Ланьчжоуском университете” (2019) и результат „Проекта демонстрационного курса „Обучение русской литературе" в Ланьчжоуском университете (2019).

Таким образом, в контексте инициативы „Один пояс и один путь” отношения Украины, Беларуси и России приводят к „новой эпохе всестороннего стратегического сотрудничества". Сотрудничество между Китаем и Украиной, Беларусью и Россией в различных областях принесло значительное обновление в нашу национальную систему обучения русскому языку. Мы полагаем, что в китайских университетах обучение русскому языку находится на хорошем уровне. Но для улучшения методической и научной подготовки специалистов мы должны использовать те возможности, которые открывает программа „Один пояс и один путь”. Перспективы нашего исследования мы видим в изучении современного состояния, проблем и перспектив изучения украинского языка в университетах Китая.

\section{Список использованной литературы}

1. Нин Ци. Обзор 70-летнего обучения русскому языку в Китае. Вестник Шанхайского университета Цзяотун (Философия и социальные науки). 2019. № 5. С. 76-88. 2. Цао Тайшэн, Лэй Ваньпэн. Реконструкция и размышление о способе совершенствования образования аспирантов от закрытого к открытому. Исследования в области развития образования. 2005. № 10. С. 15-19. 3. Чжоу Минцюань. Исследование по обучению русским талантам в контексте „Экономический пояс нового шелкового пути”. Обучение русскому языку в Китае. 2015. № 3. С. 23-27. 4. Лу Чуньюэ. Трудности и решения в преподавании русского языка на фоне „Один пояс и один путь”. Обучение русскому языку в Китае. 2019. № 4. С. $77-83$.

\section{References}

1. Nin, Tsi. (2019). Obzor 70-lietnieho obuchenyia russkomu yazyku v Kitaie [Overview of seventy years of teaching Russian in China]. Vestnik Shankhaiskogo universiteta Tsziaotun (Filosofiia $i$ sotsialnye nauki) - Bulletin of Shanghai Jiaotong University (Philosophy and Social Sciences), 5, 76-88 [in Russian]. 2. Tsao, Taishen \& Lei, Vanpen. (2005). Riekonstruktsiia i razmyshleniie o sposobie soviershienstvovaniia obrazovaniia aspirantov ot zakrytoho k otkrytomu [Reconstruction and reflection on a way to improve the education of graduate students from closed to open]. Issledovaniia $v$ oblasti razvitiia obrazovaniia Education Development Studies, 10, 15-19 [in Russian]. 3. Chzhou, Mintsiuan. (2015). Issliedovaniie po obuchieniiu russkim talantam $\mathrm{V}$ kontiekstie „Ekonomichieskii poias novoho shielkovoho puti” [Study on teaching Russian 
talent in the context of the "Economic Belt of the New Silk Road"]. Obuchenie russkomu iazyku v Kitae - Teaching Russian in China, 3, 23-27 [in Russian]. 4. Lu, Chuniue. (2019). Trudnosti i resheniia v priepodavanii russkoho yazyka na fonie „Odin poias i odin put” [Difficulties and decisions in teaching the Russian language on the background of „One belt and one way”]. Obuchenie russkomu iazyku v Kitae - Teaching Russian in China, 4, 77-83 [in Russian].

\section{Си Цзюньцінь. Навчання російській мові в китайських вишах в контексті ініціативи „Один пояс і один шлях" \\ Стаття - результат роботи двох проектів. Перший проект - „Оцінка} російських класичних літературних творів” в Ланьчжоуськом університеті” (2019). Другий проект - „Проект демонстраційного курсу „Навчання російській літературі” в Ланьчжоуському університеті” (2019). Стаття присвячена розгляду особливостей навчання російській мові в китайських вишах в контексті ініціативи „Один пояс і один шлях”. Автор зазначає, що ініціатива „Один пояс і один шлях” відкрила нові можливості для навчання російській мові в китайських вишах. В цьому контексті постійно вдосконалюється система навчання російській мові в китайських вишах. В контексті ініціативи „Один пояс і один шлях” відносини Китаю України, Білорусі та Росії також отримали новий виток у своєму розвитку. При цьому співробітництво в економічній, політичній та культурній областях збільшило попит на фахівців, які володіють російською мовою. Курси російської мови поступово включаються в такі різні області, як фінанси, торгівля, юриспруденція, медицина та інші. Щорічно державний фонд освіти відбирає та повністю субсидує найбільш успішних студентів, пов'язаних зі спеціальністю російської мови, для обміну і навчання в різних університетах України, Білорусі, Росії. У статті наголошується, що в Китаї висунуті модернізовані стандарти професійного навчання російській мові. Ця реформа в основному зачіпає професійні функції, моделі навчання майбутніх фахівців та вдосконалення команди викладачів. В Китаї університети відправляють викладачів для стажування в ті країни, де $\epsilon$ носії російської мови: в Україну, Білорусь та Росію. Все це здійснюється за підтримки державних програм і проектів Національної стипендіальної ради. Автор статті зазначає, що в університети запрошують іноземних викладачів, які $\epsilon$ носіями російської мови, це не тільки усуває брак викладачів, але й сприяє розвитку наукових досліджень за спеціальностями, пов'язаними 3 російською мовою і літературою. Автор статті вважає, що в китайських університетах навчання російській мові знаходиться на високому рівні. Але для поліпшення методичної та наукової підготовки спеціалістів треба використати ті можливості, які відкриває програма „Один пояс і один шлях".

Ключові слова: ініціатива, навчання, проблема, програма, російська мову, співпраця, університет. 
Сы Цзюньцинь. Обучение русскому языку в китайских вузах в контексте инициативы „Один пояс и один путь"

Статья - результат работы двух проектов. Первый проект „Оценка русских классических литературных произведений” в Ланьчжоуском университете” (2019). Второй проект - „Проект демонстрационного курса „Обучение русской литературе” в Ланьчжоуском университете (2019). Статья посвящена рассмотрению особенностей обучения русскому языку в китайских вузах в контексте инициативы „Один пояс и один путь”. Автор отмечает, что инициатива „Один пояс и один путь” открыла новые возможности для обучения русскому языку в китайских вузах. В этом контексте постоянно совершенствуется система обучения русскому языку в китайских вузах. В контексте инициативы „Один пояс и один путь" отношения Китая Украины, Беларуси и России также получили новый виток в своем развитии. При этом сотрудничество в экономической, политической и культурной областях увеличили спрос на специалистов, владеющих русским языком. Курсы русского языка постепенно включаются в такие различные области, как финансы, торговля, юриспруденция, медицина и другие. Ежегодно государственный фонд образования отбирает и полностью субсидирует наиболее успешных студентов, связанных со специальностью русского языка, для обмена и обучения в различных университетах Украины, Беларуси, России. В статье отмечается, что в Китае выдвинуты модернизированные стандарты профессионального обучения русскому языку. Эта реформа в основном затрагивает профессиональные функции, модели обучения будущих специалистов и совершенствование команды преподавателей. В Китае университеты оправляют преподавателей для стажировки в те страны, где есть носители русского языка: в Украину, Беларусь и Россию. Все это осуществляется при поддержке государственных программ и проектов Национального стипендиального совета. Автор статьи отмечает, что в университеты приглашают иностранных преподавателей, которые являются носителями русского языка, то это не только устраняет нехватку преподавателей, но и способствует развитию научных исследований по специальностям, связанным с русским языком и литературой. Автор статьи считает, что в китайских университетах обучение русскому языку находится на хорошем уровне. Но для улучшения методической и научной подготовки специалистов нужно использовать те возможности, которые открывает программа „Один пояс и один путь”.

Ключевые слова: инициатива, обучение, проблема, программа, русский язык, сотрудничество, университет.

Si Junqin. Teaching Russian in Chinese universities in the context of the „One Belt and One Way" Initiative

The article is the result of two projects. The first project is named „Evaluation of Russian Classical Literary Works at Lanzhou University” (2019). The second project is named „Demonstration course project 


\section{Вісник ЛНУ імені Тараса Шевченка № 3 (334), 2020}

„Teaching Russian Literature" at Lanzhou University” (2019). The author of the article writes about features of studying the Russian language at universities in China. The state has adopted the program „One belt and one path". China needs good specialists who know Russian. Different universities teach students the Russian language. Chinese universities cooperate with Ukraine, Belarus and Russia. The author of the article writes about Chinese students. Chinese students travel to other countries to study Russian. Students have good practice. Students participate in a competition where they check their skills of Russian language. If a student won the Russian Language Competition, then he goes to other countries to learn Russian. There are special audiences in China. For example, there are classrooms, where students speak only Russian. There they watch films only in Russian there. There they study Russian culture and history. There they discuss interesting issues. Chinese teachers go to other countries. Chinese teachers study Russian in these countries. They are friends with foreign teachers. They create common science projects. Foreign teachers go to China. Teachers teach Russian language. Chinese students respect foreign teachers. It is necessary to exchange teaching methods. It is necessary to study the methods of education from other countries. The author writes that it is necessary to create a group of scientists from different countries and China. This group should create new methods of teaching the Russian language. Author writes that China has a good system for learning the Russian language. All problems can be well resolved. To this day, the Chinese government has created the „One Belt and One Way" program. This program will help to solve all problems.

Key words: initiative, training, problem, program, Russian language, cooperation, university.

Стаття надійшла до редакції 21.02.2020 p.

Стаття прийнята до друку 22.02.2020 р.

Рецензент - д. філ. н., проф. В. І. Дмитренко 